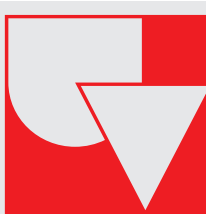

Universidad del Valle

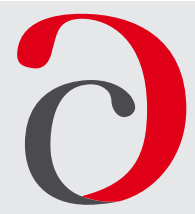

Cuadernos de Administración
Journal of Management

Print ISSN: 0120-4645 / E-ISSN: 2256-5078 / Short name: cuad.adm.

Pages: 143-157 / Vol: 36 / Issue: 67 / May - Aug. 2020

Faculty of Administration Sciences / Universidad del Valle /

Cali - Colombia

\title{
Training for professional judgment in accounting education
}

\author{
Formación para el juicio profesional en la educación contable
}

\section{Julieth Ospina Delgado(D)}

Professor and Researcher, Department of Accounting and Finance, Faculty of Economic and Administrative Sciences, Pontificia Universidad Javeriana Cali, Colombia. e-mail: yulemos@javerianacali.edu.co

\section{Ximena Giraldo Villano(D)}

Professor, Department of Accounting and Finance, Faculty of Administration Sciences, Universidad del Valle Cali, Colombia. e-mail: ximena.giraldo@correounivalle.edu.co

\author{
Article of Scientific and Technological Research \\ Submitted: 15/04/2019 \\ Reviewed: $17 / 02 / 2020$ \\ Accepted: 18/05/2020 \\ Thematic lines: Accounting \\ JEL classification: M490 \\ DOI: https://doi.org/10.25100/cdea.v36i67.7741
}

\section{Abstract}

The global convergence process towards International Financial Reporting Standards supported by multilateral agencies such as the World Bank poses a challenge to accounting education's ability to make judgments and estimates, due to the emphasis placed on general new principles-based regulation instead of detailed rules. The international literature has highlighted this aspect amply, while in Colombia, it remains incipient. This paper aims to analyze the approach to professional judgment and critical thinking in the educational proposals of high-quality Public Accounting programs in Colombia as a factor contributing to the formation of such judgment in the accountant. This paper provides empirical evidence based on a qualitative-documentary methodology, which analyzes the Educational Projects provided by accredited universities. Among the most relevant findings is the lack of an explicit statement about pedagogical strategies to materialize a professional judgment that some of the universities analyzed mentioned succinctly.

Keywords: Professional judgment, Critical thinking, Public Accounting, Accounting education.

\section{Resumen}

El proceso de convergencia global hacia las Normas Internacionales de Información Financiera, respaldado por organismos multilaterales, como el Banco Mundial, entre otros, supone un desafío para la educación contable en la capacidad de hacer juicios y estimaciones, debido al énfasis de la nueva regulación basada en principios generales y no en reglas detalladas. Este aspecto ha sido ampliamente destacado por la literatura internacional y en Colombia aún se encuentra en un estado incipiente. El objetivo de este trabajo es analizar, en los proyectos educativos de los programas de Contaduría Pública de alta calidad en Colombia, el abordaje del juicio profesional y del pensamiento crítico como un factor que contribuye a la formación de dicho juicio en el contador. Este trabajo aporta evidencia empírica, a partir de una metodología cualitativa-documental, analizando los Proyectos Educativos de Programa que se obtuvieron de las universidades acreditadas. Entre los hallazgos más relevantes se destaca la falta de declaración explícita de

Public Accountant, Universidad del Valle, Colombia, Doctor in Accounting, Universidad de Valencia, Spain.

2 Public Accountant, Master's Degree in Accounting, Universidad del Valle, Colombia. 
estrategias pedagógicas para materializar la formación del juicio profesional que, de una manera enunciativa, mencionan solo algunas de las universidades analizadas.

Palabras clave: Juicio profesional, Pensamiento crítico, Contaduría Pública, Educación contable.

\section{Introduction}

The global convergence towards International Financial Reporting Standards (IFRS) phenomenon, issued by the International Accounting Standards Board (IASB) and disseminated as the highest-quality set of global standards, also supported by several agencies (World Bank -WB-, International Monetary Fund -IMF-, Organization for Economic Cooperation and Development -OECD-, and the Group of 20 Industrialized and Emerging Countries -G20), has shed light on the need to train accountants by strengthening their professional judgment abilities. It is argued that their functional knowledge about regulations and techniques no longer suffices to adequately represent the economic reality from which different-order decisions are made. The above is supported because IFRS, "based on general principles and not on detailed rules," entail intense subjectivity and professional judgment components (Ball, 2016; Sunder, 2010). The use of professional judgment raised by the IASB in IFRS is underscored by the essenceover-form approach, as well as by the rules requiring the application of fair value and discretionary decisions (Heidhues and Patel, 2009).

The IFRS ${ }^{1}$ foundation, in the development of its IFRS Education Initiative, has included, on the one hand, the provision of e-Learning resources aimed at supporting the teaching of standards based on the Conceptual Framework approach of that set of standards. On the other hand, the conducting of regional workshops worldwide has also been included in the training of IFRS teachers and trainers based on the effective use of IFRS materials. As stated in the Guidelines for the Initiative, its objective is to "for students and SMEs to develop the ability to make the judgments necessary to implement IFRS fully and prepare students for lifelong learning" 2 (IFRS Foundation, 2015).

Colombia introduced its main change in accounting over the last two decades by the Accounting Convergence Act (Law 1314 of 2009). Because of its economic dynamics, Colombia is part of the group of emerging economies that have opted for accounting convergence expecting to obtain more significant benefits from international trade and improve productivity, competitiveness and foster the harmonious development of business activities (Law 1314, sect. 1, 2009). This law, enforceable on companies since 2015, means that Public Accounting academic programs nationwide need to implement curricular reforms to incorporate IFRS as essential knowledge for proper professional performance (Ferrer, 2013; Guerrero, Escobar, Cáceres, Rodriguez, and Flórez, 2014; Reyes and Chaparro, 2013; Rueda, Pinzón, and Patiño, 2013; Valderrama, Rodríguez, Arias, Bejarano, Garzón, Salgado, Rueda, Espinosa, and Sosa, 2009).

Given the above context, it is crucial to identify how universities state their professional judgment training in Public Accounting Educational Projects. Universities' education programs for training in accounting enunciate the need to train responsible and ethical professionals aware of their role in improving society. As such, students are regarded as playing the leading role in their training, thanks to which they will develop good judgment and professional judgment. In this regard, several studies have pointed out the importance of critical thinking in developing professional judgment, assessment, and problem-solving skills (Bucaro, 2019; Cloete, 2018; Terblanche and de Clercq, 2019). Therefore, the question arises: what is the approach to professional

1 The IFRS Foundation "is a non-profit, public interest organization established to develop a single set of high quality, comprehensible, enforceable and globally accepted accounting standards - the IFRS Standards - and to promote and facilitate the adoption of those standards" (IFRS Foundation, 2017).

2 In Colombia, there are three groups for the preparation of financial information. When talking about IFRS, reference is made to the implementation of Group 1, which applies to securities issuers, and public interest entities and businesses, as well as to entities whose workforce is over 200 employees or their assets exceed 30,000 legal minimum monthly wages in force (SMMLV per its acronym in Spanish). Group 2 refers to IFRS for SMEs, and Group 3 deals with simplified accounting. 
judgment and critical thinking in high-quality Accounting education programs in Colombia?

As a result, this paper aims to analyze the approach to professional judgment and critical thinking in high-quality Accounting education programs in Colombia to train accountants. To achieve this objective, the document was structured into five sections, the first being this introduction. Secondly, the theoretical framework offers a review and analysis of the literature produced by the rise of professional judgment in the new international regulatory models and its approach to accounting education. Likewise, the relationship between critical thinking and professional judgment in accounting is studied. The third section identifies the methodological aspects addressed to conduct the study, defining the high-quality university system, the importance of an Educational Program Project (PEP per its acronym in Spanish), and information sources. Subsequently, the results and discussion section about the statement of professional judgment in PEPs will be presented, and considerations addressed about critical thinking. Finally, the conclusions and recommendations will be laid out.

\section{Theoretical framework: professional judgment and accounting education ${ }^{3}$}

There are multiple studies on professional judgment in the practice of professional accounting (Ball, 2016; Cherry and Schwartz, 2013; Heidhues and Patel, 2009) since all professional accountants should apply it regardless of their area, given its influence on the financial information supply chain (Instituto Nacional de Contadores Públicos -INCP-, 2017) in addition to being a controversial and mostly political issue. Hence, different organizations of professional accountants around the world have created frameworks for applying professional judgment. There is evidence that standards on audit judgment for accounting estimates make audit committees more comfortable (Kang, Trotman, and Trotman, 2015).
On the other hand, training is a concept intimately linked with the subject, man and subjectivity" (Quiceno, 2002, p. 89).

Although the need for professional judgment has become more relevant on account of the IFRS, it is essential to note that Colombia made it part of the regulation and exercise of auditing and tax reviewing a long time ago (Zamora, 2016, 2018). The literature, especially international literature, about professional judgment is quite extensive in auditing, wherein the level of experience of the auditor has been linked to his professional judgment and decisionmaking abilities (Sierra and Santa Maria, 2002). However, professional judgment is not exclusive to auditing because the application of accounting standards, in general, requires skilled accountants in making judgments and estimates and to think about rules, accounting principles, why they were created, and how they could be improved. In his reflection, Zamora (2018) argues that the assessing, certifying, measuring, valuing, and reporting are public accountants' functions that require issuing a professional judgment and, therefore, consider the extent of their general knowledge and about the environment.

The term judgment has different meanings. According to Ferrater-Mora (1965), it can be defined as: "(1)... the mental act whereby we form an opinion of something. (2)... the mental process whereby we consciously decide that something is one way or another..." (1965, p. 1033). In accounting matters, judgment is associated with decision-making and involves creating an idea, opinion, criterion, or the evaluation of an object, event, or attitude. Judgment also tends to predict a future or current state of things or events and indicates the probability of occurrence. Now, decision making refers to selecting a solution and an "appropriate" course of action in which different alternatives are assessed and chosen from. In this vein, judgments reflect individual beliefs and decisions; beliefs and preferences are attached thereto (Bonner, 1999; Stojanović, 2014).

3 It is important to note that this paper uses the term education and accounting training without delving into their conceptual differences; it is not the study's purpose. However, it recognizes that "education is a concept that has borne a clear relationship with the institution, whether the former understood as a social fact, actions or values. 
Disciplinary contributions to accounting thinking and training in recent decades, which seek to promote critical and reflective judgment or thinking in students, are of great relevance. Concerns about how students prepare to assume IFRS's ambiguity and how they exercise professional judgment properly are addressed by important international literature. Han, Chand, and Mala (2019) found that IFRS-based higher education programs positively impact students' preparedness. From the perspective of generally accepted accounting principles (GAAP ), Morrill (2005) recommends emphasizing accounting theory in accounting curricula even further to improve professional judgment capabilities. This concern has motivated the study of other factors as Curtis, Vinson, Conover, Lucianetti, and Battista (2017) do when analyzing how national culture influences professionals' and students' ethical judgment.

In contrast, Colombia's publications on the matter of university education for professional judgment are still incipient. As such, this paper aims to provide empirical evidence from the standpoint of Colombian accounting education. As Avellaneda (2010) and Zamora (2016) observed, papers have been published as the product of reflections in academic events and presentations. In synthesizing some of these academic events, Guerrero et al. (2014) argue that rules-based models have strongly prevailed in Colombia, on account of which the IFRS model, based on principles vested with a highly interpretive value, represents a real challenge for professional judgment strengthening.

Undoubtedly, one of the most relevant international debates about shifting to IFRS is the importance of principled versus rulesbased regulatory models (Ball, 2016; Sunder, 2010), which makes the need for professional judgment more evident. As Carmona and Trombetta (2010) noted, this debate entails implications for accounting education because the emphasis of learning is placed on the result, and little to nothing on the fundamentals of the model when taught under rules-based models, i.e., accounting exercises' solutions are either "right," or "wrong" as per the rule, and the particular context's relevance is relegated.
Although the U.S. is notamong the countries that have implemented IFRS, for it continues to apply its local standards (USGAAP), it is an essential benchmark for the country's historically leading role in education and accounting (Pathways Commission, 2012). In their study, Carmona and Trombetta (2010) point out that accounting education in the U.S. has focused on the linear application of standards (rules-based approach) rather than the critical examination of alternative accounting processes. Their proposal for a "concept-based" education requires replacing the mechanical application of standards by a careful analysis of transactions' economic and strategic foundations for professional judgment development, a fundamental aspect in accounting and auditing tasks. For both Carmona and Trombetta (2010), and Sunder (2010), this approach will add value to professional accounting programs, leaving the current rules-based teaching modes for technical (non-professional) schools.

Other studies from the Spanish (Carmona, 2013; Gonzalo-Angulo, 2014), German (Heidhues and Patel, 2009), and French contexts (Chabrak and Craig, 2013) agree that technical approaches and rules-based instrumentation continue to prevail. In the context of developing countries, Chand (2005) identified deficiencies in accounting education as demonstrated by previous studies, arguing that a country cannot expect accountants to exercise their professional judgment properly under such circumstances.

\subsection{Critical thinking and professional judgment}

Concerning higher education studies, Altuve (2010) states that some critical thinking characteristics relate to the formulation of fundamental problems and questions, reaching conclusions and reasoned solutions, and to an open mind within alternative systems of thought, and recognizing and evaluating assumptions, their implications, and practical consequences. Such critical thinking or judgment should also be "oriented to understanding and problem-solving, evaluating alternatives and decision-making" (Bezanilla, Poblete, Fernández, Arranz, and 
Campo, 2018, p. 95). He who cultivates a critical spirit "knows how to see the logical and argumentative fissures of a theory, its symptoms, its gaps, its suspicious silences" (Cruz, 2007). Therefore, critical thinking is essential in vocational training and is not limited to scientific training.

International literature on accounting (Ball, 2016; Cherry and Schwartz, 2013; Sunder, 2010) has widely pointed out the need for university programs to teach general principles rather than technical skills typical of other training types. The strengthening of abstraction and critical thinking capabilities in students enables them to comprehend the shift in standards and apply them to specific transactions, using the professional judgment developed through education about general principles.

It is argued that accounting and auditing are seeing a growing demand for more critical and thoughtful analysis, especially in a technology-driven world (Bucaro, 2019; Cloete, 2018; Terblanche and de Clercq, 2019). Some studies indicate that auditors tend to make mechanistic decisions in situations that require their complexity to be assessed, and professional judgment to be applied thereunto more effectively (Gao and Zhang, 2019). Following this train of thought, academic programs implement several educational methodologies and strategies to foster critical thinking. Bucaro (2019) posits that improving professional judgment requires working on changing auditors' thinking and strengthening critical thinking skills, for which the above-authors recommends system dynamics. Moreover, Cloete (2018) emphasizes the importance of implementing integrated assessments based on actual cases throughout the curriculum and not just in the first year of studies or at some specific moments.

Initiatives proposed to improve critical thinking in students demand efforts to link accounting issues to the social world, and thus demystify the supposed naturalness of the capitalist system and encourage students to imagine other discourses that challenge any prevailing ideology (Chabrak and Craig, 2013; McPhail, 1999). Debates are among the pedagogical tools used to improve critical thinking skills; however, Camp and Schnader
(2010) have shown that this tool is often not used effectively in accounting teaching. In this sense, the mere listing of such tools in the curricula is only the first step.

Critical thinking in accountants' training comes from education models that incorporate theories of learning, and pedagogical models that privilege students' critical, analytical, and propositional discernment capabilities. Gómez, Monroy, and Bonilla (2019) assert that such critical abilities and skills are possible through investigative curiosity, systemic doubt, and skepticism, essential elements for professional judgment.

Accounting literature nationwide (Ariza, 2008; García-Jiménez, 2014; Gómez et al., 2019; Gómez-Villegas, 2007, 2010; Martínez, 2007; Muñoz, Ruiz, and Sarmiento, 2015; Ospina, 2009; Ospina and Rojas, 2011; Quijano, 2002; Rojas and Giraldo, 2015; Rueda et al., 2013) has shed light on accountants' need for comprehensive training to meet social requirements, and develop cognitive, procedural and attitudinal capabilities in a balanced manner, thereby fostering stronger critical thinking skills. An accountant that it is critical and less norm-focused, in such a way so as to assume the complexity of different local and global contexts, incorporating technical qualifications, humanistic training, and development of critical and research capabilities. In the same way, it would allow students to understand that "norms are presented as a depoliticized instrument (...) that configures transnational territories and ignores the problems and assumptions of contemporary thinking and living" (Rojas, 2015, p. 321).

Concerning the above, the technical teaching of standards has also been internationally recognized to limit future accountants' possibilities to contribute from their discipline to a social and political construct that differs from that which international standards and their ideology promote (Chabrak and Craig, 2013; McPhail, 1999; Rueda et al. , 2013). Therefore, it is understood that pedagogical models should rethink how accounting professionals are trained.

The International Federation Accountant Certified (IFAC) sets worldwide standards 
associated with accounting and accounting education. According to these standards, critical analysis is an intellectual ability that, together with logical and abstract thinking, allows professionals to solve problems by considering different alternatives and analyzing potential outcomes. Meanwhile, professional judgment is posed as an attitude that enables informed decision making regarding the courses of action that might be appropriate under specific circumstances (IFAC, 2015, IES 8). IFAC's approach proposes professional judgment as a concept associated with ethics, which must be strengthened through experience. It requires strengthening in the initial stages of professional training through general education and critical analysis. Furthermore, in the International Standard of Auditing, IFAC characterizes professional judgment as the:

... application of relevant practical training, knowledge, and experience in the contexts of auditing, accounting, and ethics standards, for informed decision-making about the appropriate course of action depending on the audit assignment's circumstances. (International Auditing Standard 200, 2009, paragraph k).

Nevertheless, as some studies suggest (Chabrak and Craig, 2013; Kang et al., 2015; Gao and Zhang, 2019), the exercise of professional judgment may be restricted by the rules. Gao and Zhang (2019) studied this phenomenon in auditors and identified an extensive mindset of mere compliance, wherein quality and professional competence are set aside. Therefore, critical thinking should enable professionals to understand that professional judgment, as conceived by these international organizations, is embedded in business practice contexts. The logic of which leads to skewed judgment because these practices are based on maximizing utility for investors, as Chabrak and Craig (2013) and McPhail (1999) have pointed out.

It is also necessary to debate whether accounting experience is the best way to strengthen professional judgment. Karim Jamal, a participant in the Canadian forum on professional judgment teaching in accounting, published in Correll, Jamal, and Robinson (2007), argues that accounting practices are not the right learning environment. On the contrary, when an accountant makes a decision, a long time passes by to get a reaction or see its effect, and it is often unclear whether what they did was right or wrong. In this sense, delayed feedback degrades learning, which works differently in medicine or law, where professional performance can be observed instantaneously and correctly fed back to apprentices.

Although experience is of great value to expertise as it consolidates over time, it is not enough for the mastery of professional knowledge because business practices' essence is redefined continuously by market rules. These are also not concerned with problematizing general or accounting knowledge or thinking critically about society and governing rationality. It is universities that are considered privileged spaces for man, society, and science to think critically. To that end, "critical reading and writing as a "toolbox" (...) to build critical thinking" (Rojas, 2015, p. 314) are fundamental. Pedagogies that promote reading and writing and critical thinking, as proposed by Rojas (2015), prepare university students to assess the multiple alternatives to a decision and not be captured by society's contradictions.

Similarly, Correll et al. (2007) sustain that accounting education needs to learn from law schools. The latter not only fosters respect for rules and norms but learning on how to challenge them and create new arguments for modifying or creating new laws. To do this, "principles should be presented as the minimum standard and not as the maximum to achieve, and motivate students to wonder how to present financial information better than the principles' minimum standard require" (p. 127).

As a social institution, universities should be concerned with students being aware of the paradigms and approaches that underlie their knowledge. In this sense, it is necessary to recognize that universities provide students with "professional training in accountant or administration without ever asking about the causality and effectiveness relationships, or about the actual "logic" that dominate the world of business and economics" (Cruz, 2007, p. 205-206). Therefore, any academic program that considers these aspects should 
problematize them in their educational project.

\section{Methodological aspects}

This paper used a qualitativedocumentary methodology paired with an analytical perspective of Public Accounting's Educational Projects (PEP) as provided by high-quality university programs accredited by the Ministry of Education of Colombia. The following paragraphs describe the quality management system that governs universities, which we held as criteria to select the institutions analyzed. Below are some considerations about PEPs as this study's subject of analysis.

\subsection{High-quality accreditation}

The Ministry of National Education (MEN per its acronym in Spanish) established the quality assurance system for higher education through two levels. The first level, known as Qualified Registry, is regulated by Decree 1295 of April 2010, which provides the quality conditions for offering and developing academic programs. The second level is High-Quality Accreditation, which is awarded to programs and institutions that voluntarily underwent this assessment (Consejo Nacional de Acreditación (CNA per its acronym in Spanish, 2013).

Colombia's CNA provides that an academic program will be high-quality to the extent that it implements its educational project. In addition to being a document of the public domain, institutions' educational projects must be "consistent with the institution's project, and the professional or disciplinary fields. It must also provide objectives, basic curriculum guidelines, development goals, policies, planning, and evaluation strategies, and the quality assurance system" (ANC, per its acronym in Spanish, 2013, p. 20).

\subsection{Educational Program Project}

PEPs reflect the program's raining process's identity. As defined by the Universidad Nacional, it is a document that works as the navigation chart within wanting-to-be academic and argumentative exercises (Universidad Nacional de Colombia, 2012). In this vein, the above must be aligned with the university's institutional project, that is, determining how the mission, principles, institutional values are materialized and their coherence with accounting's formative meaning in the national and local realms (Valderrama et al., 2009). Thus, as proposed by Ospina and Rojas (2011), PEPs are specific to each program. With it, teachers and students understand the main theoretical and methodological problems of their knowledge and recognize the employment and defense of the public interest in professional practice.

In their research on Accounting-related PEPs from three high-quality accredited universities in Antioquia (Colombia), Pinilla and Martínez (2015) propose the existence of multiple types of PEPs with different structures. They argue that this document should address at least four (4) aspects: pedagogy, curriculum, didactics, and administrative management. In contrast, Ospina and Rojas (2011) propose that PEPs should address three fundamental aspects: disciplinary perspectives and professional development fields in tune with the university's and the program's mission and vision; assimilation of moral postulates and ethical principles to guarantee a professional exercise framed in respect for cultural diversity and ideological pluralism; and educational concepts that concretize the purpose of training, i.e., curriculum, pedagogy, didactics, and evaluation.

\subsection{Sources and data}

According to the National Higher Education Information System (SNIES per its acronym in Spanish), there are 238 professional Public Accounting programs as of the date of this study, of which only 30 (12.6\%) were high-quality accredited as of July 2018 (MEN, 2018). This study considered those offered by institutions bearing university status, namely, active programs from 28 universities using a face-to-face methodology and are offered on a biannual basis. Twenty-eight programs were the universe of data, and information was obtained from 50\%; that is, we had a sample of 14 PEPs for our analysis (Table 1). 


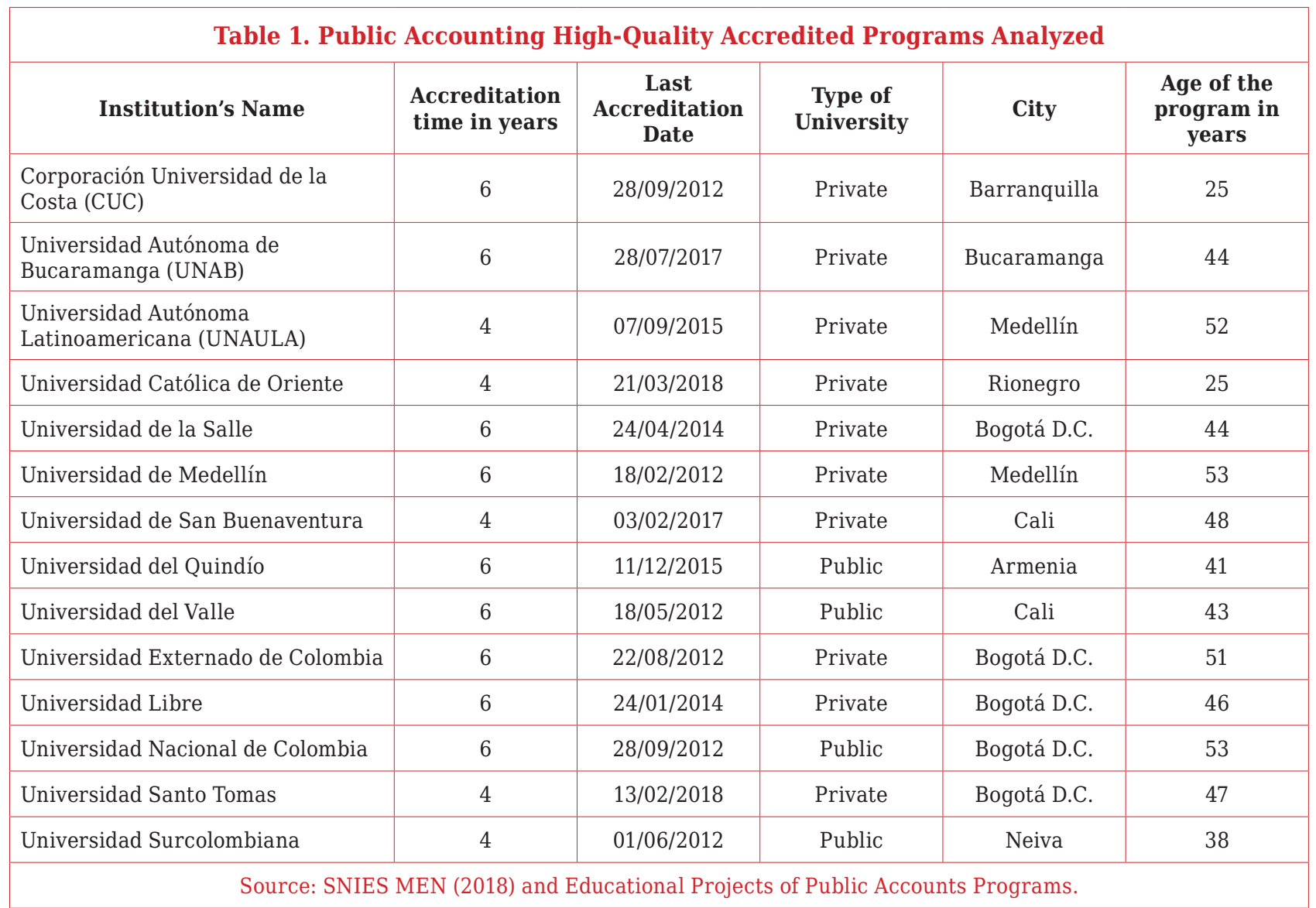

The source of PEPs were the institutions' websites, and in some cases, the institutions' directives themselves provided the PEPs in response to our request via e-mail. It is essential to clarify that the criteria for including institutions in this analysis, apart from national accreditation, was to have an official document called the Educational Program Project.

It is worth clarifying, for methodological purposes, that in the case of the Universidad de Antioquia, despite having a high-quality accredited Accounting program and a large number of institutional publications on accounting education, it was not included in the study because it lacked a PEP. The work of Pinilla and Martínez (2015), which evaluated the University of Antioquia's PEP, considered the said University's PEP as part of an editorial publication entitled "Recreando el Curriculum (Recreating the Curriculum)" in 2006.

Based on the literature reviewed on professional judgment and critical thinking, and an analysis of the PEPs revealed what each institution asserts concerning these two aspects regarding professional training for accountants. The analysis took into account the context in which the term is used. Hence, instead of "professional judgment," the use of "judgment" or "criterion" was considered valid as long as it referred to professionals' scope of performance. Similarly, in the case of "critical thinking," the term "critical judgment" was also included for analysis.

Table 2 shows the references that each institution makes about professional judgment and critical thinking in its PEP, indicating the document's sections that include these expressions.

\section{Results and discussion}

As shown in Table 1, public accounting programs have an over-25-year history. These programs can be said to have consolidated an educational project that one would expect to find, as proposed by Cruz (2007), a stated commitment to critical training to decant the economic and financial logic from which 
Table 2. References to professional judgment and critical thinking

\begin{tabular}{|c|c|c|c|}
\hline Institution's Name & Source & $\begin{array}{l}\text { The portion of the document } \\
\text { mentioning professional } \\
\text { judgment }\end{array}$ & $\begin{array}{l}\text { The portion of the document } \\
\text { mentioning Critical Thinking }\end{array}$ \\
\hline $\begin{array}{l}\text { Corporación Universidad de la } \\
\text { Costa (CUC) }\end{array}$ & PEP 2015 & None & $\begin{array}{c}\text { Specific objectives } \\
\text { Problem-based pedagogy }\end{array}$ \\
\hline $\begin{array}{l}\text { Universidad Autónoma de } \\
\text { Bucaramanga (UNAB) }\end{array}$ & PEP 2017 & Competencies & $\begin{array}{l}\text { Pedagogical strategies in Accounting } \\
\text { Theory. Simulation and Case Studies }\end{array}$ \\
\hline $\begin{array}{c}\text { Universidad Autónoma } \\
\text { Latinoamericana (UNAULA) }\end{array}$ & PEP 2013 & Graduate Profile & Graduate Profile \\
\hline $\begin{array}{l}\text { Universidad Católica de } \\
\text { Oriente }\end{array}$ & $\begin{array}{l}\text { PEP V:3 } \\
2016\end{array}$ & $\begin{array}{c}\text { Specific Objectives } \\
\text { Accounting Practice Office }\end{array}$ & Professional profile \\
\hline Universidad de Medellín & PEP 2017 & $\begin{array}{l}\text { Intellectual and professional } \\
\text { competencies based on } \\
\text { IFAC-IAESB }\end{array}$ & Pedagogical strategies \\
\hline Universidad del Quindío & PEP & $\begin{array}{l}\text { Competencies } \\
\text { Training purposes }\end{array}$ & $\begin{array}{l}\text { Didactic strategies: Problem-Based } \\
\text { Pedagogy, Learning by Discovery, } \\
\text { Cooperative, and Significant Learning }\end{array}$ \\
\hline Universidad del Valle & PEP 2011 & $\begin{array}{l}\text { The ethical-political subject to } \\
\text { be trained. Objectives related to } \\
\text { know-how }\end{array}$ & $\begin{array}{l}\text { Purpose of training. The cross-sectional } \\
\text { axis of the curriculum. Training contexts }\end{array}$ \\
\hline $\begin{array}{l}\text { Universidad Externado de } \\
\text { Colombia }\end{array}$ & PAF 2011 & None & $\begin{array}{l}\text { Introduction/vision of the profession/ } \\
\text { objectives }\end{array}$ \\
\hline Universidad Libre de Bogotá & PEP 2017 & $\begin{array}{l}\text { Objectives of the educational } \\
\text { project }\end{array}$ & $\begin{array}{c}\text { Principles and values. } \\
\text { Universidad Libre training. } \\
\text { Curricular Model Based on Financial } \\
\text { Operations Cycles }\end{array}$ \\
\hline $\begin{array}{l}\text { Universidad Nacional de } \\
\text { Colombia }\end{array}$ & PEP 2013 & $\begin{array}{l}\text { Public Accountants' Capabilities } \\
\text { and competencies. }\end{array}$ & $\begin{array}{l}\text { Origin and evolution of the program. } \\
\text { Methodology in the areas of accounting } \\
\text { theories and models }\end{array}$ \\
\hline Universidad Santo Tomas & PEP 2013 & None & Graduate profiles \\
\hline Universidad Surcolombiana & PEP & None & $\begin{array}{l}\text { University Principles } \\
\text { Program Principles }\end{array}$ \\
\hline Universidad de la Salle & PEP & None & None \\
\hline $\begin{array}{l}\text { Universidad de San } \\
\text { Buenaventura }\end{array}$ & PEP 2015 & None & None \\
\hline
\end{tabular}

accounting knowledge emerges, allowing professionals to develop innovative views.

Also, considering that Colombia decided to change its accounting model in 2009, we expected to find the programs' approach to the implications for training in professional judgment, which is based on the international literature as "shifting from a detailed rulesbased approach to a general principlesbased approach." This aspect is also part of the requirements issued by IFAC and IASB, whose approaches and set of standards are generally accepted in Colombia. Despite this topic's international relevance, there was no evidence of the programs' explicit institutional reference to these matters.
Although several of the PEPs analyzed include a section about the current and prospective disciplinary status of Accounting at the national and international levels, these views do not materialize in specific pedagogical statements. As an example, here is the case of a university that proposes a critical view of the current model:

Nowadays, accounting in Colombia is limited to compliance with legal regulations where nothing constructive is provided for the economic entity, and there is no application of professional criteria. In general, regulations unrelated to our cultural context and identity are being accepted. We have dedicated ourselves to copying other societies' accounting rules 
that, by some account, are considered better, superior, appropriating humbly yet without authenticity, instead of building our regulations to fit the Colombian environment (Universidad Católica de Oriente, 2016, p. 30).

Furthermore, the above quote refers to the regulatory compliance approach of accounting, and its impact on the lack of application of professional criteria, a consideration that has been referred to in prior literature.

A noteworthy general remark is that most PEPs analyzed follow a structure that is abbreviated or similar to that required by the CNA for self-assessment purposes in highquality accreditation processes. In contrast to previous literature, the programs are still far from consolidating a document with all the components expected of a PEP.

From the individual analysis carried out on each PEP, it was possible to identify that eight (8) programs explicitly mentioned, in different sections of the document, training for professional judgment (Table 2). However, there is no reference to the debate on training in general principles versus detailed rules. The sections mentioning professional judgment and critical thinking were grouped into: i) professional profiles and training objectives; ii) skills and competencies; and iii) pedagogical strategies.

The expression "professional judgment" in the analyzed PEPs was found in one of the three common themes already mentioned. This means that this expression is held more as an ideal to achieve, an objective, a competency of the program's future graduates. However, little or nothing is proposed about the methods and pedagogies necessary to develop it. In one case, a closer description as to how the program intends to achieve its training purpose was provided, thus evidencing its commitment to practical training:

An excellent complement to the theory is the practical application of the foundations that students gain in the course of the program because this allows them to transfer their knowledge to a practical reality, which essentially challenges them into corroborating their aptitudes and testing their analysis and discernment capabilities in relation to the variables the environment where they are to develop professionally presents them with. This is the Universidad Católica de Oriente's Public Accounting Program incorporated its Accounting Practice Office intending to project the major and the institution towards society and provide students with a space that allows them to practice their knowledge and abilities. There, they are able to create, research, and develop those elements of judgment that will endorse the performance of their functions after concluding their academic cycle and move on to the development of their careers with the credibility and status it demands (Universidad Católica de Oriente, 2016, p. 27).

As for the promotion of critical thinking, 13 out of 14 programs analyzed addressed this purpose; that is, academic programs have broadly embraced the need to contribute to this type of training, compared to professional judgment.

Although most programs contemplate critical thinking in their educational projects, none linked the pedagogical strategies for addressing professional judgment training needs. Nor do they refer to critical thinking's relevance in applying and interpreting general principles rather than detailed rules. Several programs even consider the promotion of thinking as part of some training areas such as research or accounting theory, but not as part of an integrated training throughout the curriculum.

Some of the educational projects' strategies to promote critical thinking consist of case studies and simulations that facilitate the staging of professional scenarios that require the application of professional judgment. However, as Cloete (2018) stated, in most cases, these strategies are proposed during specific stages of the major and not as a constant training tool.

The results show an entry-level approach to the study of professional judgment from Accredited Accounting PEPs in Colombia. In the future, this type of research should be delved into by other methodologies that expand on sources of information. The results' non-generalization is a limitation to this study, given that the analysis revolves around the revised programs. 


\section{Conclusions and recommendations}

The educational projects analyzed, in general, reflect the absence of a pedagogical approach at the institutional level to the normative and political changes and the changes in accounting over the last decade, widely referenced in national and international literature. Public Accounting PEPs in Colombia still do not allow general readers and the students to recognize the institution's vision of the professional issues it considers key in its academic offer, the addressing of which increasingly requires employing professional judgment.

Public Accounting programs that have implemented high-quality models tend to develop their PEP according to the CNA guideline for the self-assessment process for accreditation purposes. This observation makes it possible to explain, to no small extent, two aspects. Firstly, it explains why these institutional documents are prepared somewhat as a requirement to be met than precisely designing and specifying their training project's key issues, such as the program's proposal of ideal training. Secondly, it also explains why the debates proposed, and reflections made by the national academic community have not been incorporated, which their publications do reflect.

For this aspect of accounting education, Ospina and Castaño's (2012) affirmation could be generalized regarding accounting theory in the sense that most academic contributions "come from restless spirits rather than most institutions' committed work" (p. 251). The above, taking into account that there are over 230 Public Accounting professional programs in Colombia, of which just over $12 \%$ are high-quality accredited. Moreover, PEPs should be a public-domain document; only $50 \%$ of the accredited programs could be obtained for this work.

Although the programs analyzed are over 25 years old, and according to the literature mentioned above, there is no majority commitment to training in critical thinking to allow students to place accounting knowledge in the current economic system and imagine other innovative logic that would reduce inequalities in the social realm.
Academic programs in Colombia should incorporate the discussion of training in professional judgment and identify the implications thereof for their educational project. They should also include the debate about in general principles-oriented training versus detailed rules-oriented. Although 57\% of the projects analyzed (8 out of 14) make an explicit statement of the need to shape professional judgment, none of them placed this purpose within the international debate framework. Nor were there references to the IFRS Foundation's strategy for teaching the conceptual framework conducive to developing students' professional judgment abilities.

Critical thinking was also analyzed as a concept that contributes and improves training in accountants' professional judgment, which has been a pressing matter in universities given higher education's general requirements for integral training. Nevertheless, according to the results obtained, we see that critical thinking-based discussions and progress in accounting have not materialized in educational projects the way they have in nationwide accountingrelated reading. Even though 93\% of the projects analyzed (13 out of 14) refer to critical thinking in students' training, none of them linked this purpose to professional judgment shaping.

Our documentary analysis made it possible to highlight Colombia's need for an institutional commitment concerned with constructing teachers' support material such as cases and simulators, among others, that favor the development of critical thinking and professional judgment skills. An insignificant number of educational projects described their application of this type of resource.

The literature analyzed provides evidence on the need for empirical research to account for the implementation of the new IFRS accounting model regarding Public Accounting academic programs' training in professional judgment, since Colombia's accounting education research on the matter remains at an early stage.

Intending to contribute in this line of knowledge, and based on Colombia's Highquality Public Accounting programs, this 
paper allows us to affirm that a decade after the enactment of the law that shifted accounting towards IFRS, professional accounting training programs have a significant road ahead of themselves to make explicit the pedagogical transformations they claim to have undertaken to address this new regulatory model "based on general principles instead of detailed rules." Although quality accreditation processes generate new dynamics to educational programs, and it cannot go unacknowledged that these have improved the offer's conditions, there is still no need to delve deeper into this path to assure quality. Universities should incorporate into their activities the debate about the whats and whys of their methods to ensure compliance with their promise of quality to Public Accounting students. In this vein, institutions must undertake their tasks towards the construction of educational projects that recognize the fundamental problems of the discipline and the professional field that the graduate must face and solve and guarantee pedagogies that link critical thinking to their training. High-quality accreditations should lead to improvement, as mentioned earlier.

\section{Conflict of interest}

The authors declare no conflict of interest.

\section{Source of Financing}

This is the outcome of the project entitled "Current status, possibilities and limitations of training for professional judgment in accounting education in Colombian Professional Public Accounting programs, attached to the research group Pensamiento y Praxis (Though and Praxis) and financed by the Pontificia Universidad Javeriana Cali. Internal code 264. The authors thank Professor Jhonny Grajales Quintero's contributions in conceiving the project.

\section{References}

Altuve, J. (2010). El pensamiento crítico y su inserción en la educación superior. Actualidad Contable FACES, 20, 5-18. Recuperado de https://www.redalyc.org/pdf/257/25715828002. pdf
Ariza, D. (2008). Transformaciones contextuales, disciplinares y del pensum de Contaduría Pública: un análisis relacional. Revista Facultad de Ciencias Económicas: Investigación y Reflexión, XVI(1), 217-232. Recuperado de https://www.redalyc.org/articulo. oa? id=90916115\&idp=1\&cid=980991

Avellaneda, C. (2010). Factores de incidencia de la Ley 1314 de 2009 en la Educación Contable colombiana. Criterio Libre, 8(12), 209-237. Recuperado de https://dialnet.unirioja.es/ servlet/articulo?codigo $=3302896$

Ball, R. (2016). IFRS 10 Years later. Accounting and Business Research, 46(5), 545-571. https:/l doi.org/10.1080/00014788.2016.1182710

Bezanilla, M., Poblete, M., Fernández, D., Arranz, S., y Campo, L. (2018). El Pensamiento crítico desde la perspectiva de los docentes universitarios. Estudios Pedagógicos XLIV, (1), 89-113. Recuperado de https://scielo. conicyt.cl/pdf/estped/v44n1/0718-0705estped-44-01-00089.pdf

Bonner, S. (1999). Judgment and Decision-Making. Research in Accounting. Accounting Horizons, 13(4), 385-398. https://doi.org/10.2308/ acch.1999.13.4.385

Bucaro, A. C. (2019). Enhancing auditors' critical thinking in audits of complex estimates. Accounting, Organizations and Society, 73, 3549. https://doi.org/10.1016/j.aos.2018.06.002

Camp, J. M., \& Schnader, A. L. (2010). Using debate to enhance critical thinking in the accounting classroom: The Sarbanes-Oxley act and U.S. tax policy. Issues in Accounting Education, 25(4), 655-675. https://doi.org/10.2308/ iace.2010.25.4.655

Carmona, S., \& Trombetta, M. (2010). The IASB and FASB convergence process and the need for 'concept-based' accounting teaching. Advances in Accounting, incorporating Advances in International Accounting, 26, 1-5. https://doi. org/10.1016/j.adiac.2010.03.003

Carmona, S. (2013). Accounting curriculum reform? The devil is in the detail. Critical Perspectives on Accounting, 24, 113-119. https:// doi.org/10.1016/j.cpa.2012.03.004

Chabrak, N., \& Craig, R. (2013). Studentimaginings, cognitive dissonance and critical thinking. Critical Perspectives on Accounting, 24(2), 91104. https://doi.org/10.1016/j.cpa.2011.07.008

Chand, P. (2005). Impetus to the success of harmonization: the case of South Pacific Island Nations. Critical Perspectives on Accounting, 
16(3), 209-226. https://doi.org/10.1016/j. сра.2003.06.002

Cherry, A., \& Schwartz, B. N. (2013). What's the rush? IFRS, the SEC, and the pressure on accounting instructors to teach still more financial reporting rules. American Journal of Business Education, 6(2), 161-176. https://doi. org/10.19030/ajbe.v6i2.7708

Cloete, M. (2018). The impact of an integrated assessment on the critical thinking skills of first-year university students. Accounting Education, 27(5), 479-494. https://doi.org/10.10 $\underline{80 / 09639284.2018 .1501717}$

Consejo Nacional de Acreditación. (2013). Lineamientos para la acreditación de programas de pregrado. Bogotá, Colombia: CNA. Recuperado de https://www.cna.gov.co/1741/ articles-186359 pregrado_2013.pdf

Correll, R., Jamal, K., \& Robinson, L. (2007). Forum Teaching Professional Judgement in Accounting. Accounting Perspectives, 6(2), 123-140. https:/l doi.org/10.1506/0007-K110-44W0-UL3T

Cruz, F. (2007). La derrota de la luz. Ensayo sobre modernidad, contemporaneidad y cultura. Cali, Colombia: Editorial Universidad del Valle.

Curtis, M., Vinson, J., Conover, T., Lucianetti, L., \& Battista, V. (2017). National Culture and Ethical Judgment: A Social Contract Approach to the Contrast of Ethical Decision Making by Accounting Professionals and Students from the U.S. and Italy. Journal of International Accounting Research, 16(2), 103-120. https://doi. org/10.2308/jiar-51824

Decreto $\mathrm{N}^{\circ}$ 1295. (2010, abril). Por el cual se reglamenta el registro calificado de que trata la Ley 1188 de 2008 y la oferta y desarrollo de programas académicos de educación superior. Colombia: Ministerio de Educación Nacional. Recuperado de http://www.suin-juriscol.gov.co/ viewDocument.asp?ruta=Decretos $/ 1261393$

Ferrater-Mora, J. (1965). Diccionario de filosofía. Buenos Aires, Argentina: Sudamericana. Recuperado de: https://www. lacanterafreudiana.com.ar/Ferrater $\% 20$ Mora\%20-\%20Dicc\%20de\%20Filosofia\%20J. PDF

Ferrer, A. (2013). Análisis del proceso de convergencia a Normas Internacionales de Contabilidad e Información Financiera desde los factores intrínsecos al sistema contable en Colombia. Cuadernos de Contabilidad, 14(36), 971-1007. Recuperado de http:/l www.scielo.org.co/scielo.php?pid=S0123-
$14722013000300005 \&$ script $=$ sci

abstract\&tlng $=$ es

Gao, P., \& Zhang, G. (2019). Auditing Standards, Professional Judgment, and Audit Quality. The Accounting Review, 94(6), 201-225. https://doi. org/10.2308/accr-52389

García-Jiménez, M. (2014). Enseñanza de la contabilidad como disciplina académica: Concepciones de ciencias del profesorado y pensamiento crítico. Entramado, 10(1), 164-174. Recuperado de http://www. scielo.org.co/scielo.php?pid=S1900$\underline{38032014000100010 \& \text { script }=\text { sci }}$ abstract\&tlng $=e s$

Gómez, J., Monroy, L., y Bonilla, C. (2019). Caracterización de los modelos pedagógicos y su pertinencia en una educación contable crítica. Entramado, 15(1), 164-189. Recuperado de http://www.scielo.org.co/pdf/entra/ v15n1/1900-3803-entra-15-01-164.pdf

Gómez-Villegas, M. (2007). Comprendiendo las relaciones entre los sistemas contables, los modelos contables y los sistemas de información contables empresariales. Revista Internacional Legis de Contabilidad y Auditoría, 32, (83-114). Recuperado de https://xperta.legis.co/visor/ temp rcontador 1aab1ff2-9560-4d44-b19d4288288328c6

Gómez-Villegas, M. (2010). Pensando los fundamentos de la contabilidad como disciplina académica. Lúmina, 12, 120-150. https://doi. org/10.30554/lumina.12.696.2011

Gonzalo-Angulo, J.A. (2014). La reforma contable española de 2007: un balance. $R C$ SAR, 17(2), 183-200. https://doi.org/10.1016/j. rCsar.2014.09.001

Guerrero, J., Escobar, M., Cáceres, L., Rodríguez, F., y Flórez, E. (2014). Marco conceptual de la información financiera: reflexiones y experiencias desde la academia y el ejercicio profesional. Revista Internacional Legis de Contabilidad y Auditoría (58), 115-134. Recuperado de https://xperta.legis.co/visor/ temp rcontador fe38f471-96db-4440-a889b986̄ dfd26ac

Han Y., Chand P., \& Mala R. (2019). Impact of ambiguity tolerance and tertiary education on professional judgment. Accounting Forum, 43(4), 426-447. https://doi.org/10.1080/0155998 2.2019 .1569813

Heidhues, E., \& Patel, C. (2009). IFRS and Exercise of Accountants Professional Judgments: Insights and Concerns from a German Perspective (pp. 
1-47). In A. Cheng (Ed.), IAAER \& ANPCONT $\left(3^{\text {rd }}\right)$ International Accounting Congress Sao Paulo: IAAER - International Association for Accounting Education and Research.

IFRS Foundation. (2015). A Guide to the IFRS Education Initiative. United Kingdom: IFRS Foundation Publication Department.

IFRS Foundation. (2017). IFRS. United Kingdom: IFRS Foundation. Retrieved from https://www. ifrs.org/about-us/who-we-are/

INCP. (2017). El comité de contadores profesionales en ejercicio responde al proyecto de discusión pública de IESBA sobre escepticismo $y$ juicio profesional. Bogotá, Colombia: INCP. Recuperado de https://www.incp.org.co/ comite-contadores-profesionales-ejercicioresponde-al-proyecto-discusion-publica-iesbaescepticismo-juicio-profesional/

International Federation of Accountants (IFAC). (2015). Handbook of international education pronouncements. New York: USA. International Federation of Accountants. Recuperado de https://www.ifac.org/system/files/publications/ files/IAESB-2015-Handbook 0.pdf

Kang Y. J., Trotman A. J., \& Trotman, K. T. (2015). The effect of an Audit Judgment Rule on audit committee members' professional skepticism: The case of accounting estimates. Accounting, Organizations and Society, 46, 59-76. https://doi. org/10.1016/j.aos.2015.03.001

Ley 1314. (2009, julio). Por la cual se regulan los principios y normas de contabilidad $e$ información financiera y de aseguramiento de información. Diario Oficial No. 47.409 de 13 de julio de 2009. Bogotá, Colombia: Ministerio de Hacienda y Crédito Público, y Ministerio del Comercio, Industria y Turismo. Recuperado de http://www.secretariasenado.gov.co/senado/ basedoc/ley_1314_2009.html

Martínez, G. L. (2007). La educación contable en el nuevo contexto de significación. Contaduría Universidad de Antioquia, 50, 43-76. Recuperado de https://revistas.udea.edu.co/index.php/cont/ article/view/2121

McPhail, K. (1999). The Threat of Ethical Accountants: An Application of Foucault's Concept of Ethics to Accounting Education and Some Thoughts on Ethically Educating For The Other. Critical Perspectives on Accounting, 10(6), 833-866. $\quad$ https://doi.org/10.1006/ cpac. 1998.0277

Ministerio de Educación Nacional (MEN). (2018). Sistema Nacional de Información de la
Educación Superior. Recuperado de https:// www.mineducacion.gov.co/sistemasinfo/snies/

Morrill, J. (2005). Professional judgment and departures from GAAP: "judgment in jeopardy" revisited. Canadian Accounting Perspectives, 4(2), 285-299. $\quad$ https://doi.org/10.1506/ DYU3-HRG8-CXP7-4LAD

Muñoz, S., Ruíz, G., y Sarmiento, H. (2015). Didácticas para la formación en investigación contable: una discusión crítica de las prácticas de enseñanza. Revista de la Facultad de Ciencias Económicas de la Universidad Militar Nueva Granada. rev.fac.cienc.econ, XXIII(1), 5386. Recuperado de http://www.scielo.org.co/ pdf/rfce/v23n1/v23n1a04.pdf

Norma Internacional de Auditoría 200. (2009). Objetivos globales del auditor independiente $y$ realización de la auditoría de conformidad con las normas internacionales de auditoría. Bogotá, Colombia: Instituto Nacional de Contadores Públicos. Recuperado de https://incp.org.co/ Site/publicaciones/info/archivos/NIA-20011092018.pdf

Ospina, C. (2009). Educación Contable en Colombia. Sentires de algunos actores y la educación contable como acción educativa. Contaduría, 55, 11-40. Recuperado de https:// revistas.udea.edu.co/index.php/cont/article/ view/16336/14169

Ospina, C., y Castaño, C. (2012). El campo de la teoría contable. Distinciones centrales para subrayar el papel de la Universidad de Antioquia en el contexto colombiano. En M. Machado (Ed.), Huellas y Devenir Contable (pp. 222-275). Colombia: Departamento de Ciencias Contables, Universidad de Antioquia. Recuperado de https://www.researchgate.net/ publication/335753895 EL_CAMPO DE LA TEORIA CONTABLE Distinciones centrales para_subrayar_el_papel_de la Universidad de_Antioquia_èn_el_contexto_colombiano

Ospina, C., y Rojas, W. (2011). Consideraciones sobre el sentido de un proyecto educativo en Contaduría Pública. Cuadernos de Administración, 27(45), 45-60. https://doi. org/10.25100/cdea.v27i45.443

Pathways Commission. (2012). Charting a national strategy for the next generation of accountants. Sponsored by the American Accounting Association (AAA) and American Institute of CPA's (AICPA). Recuperado de http://commons. aaahq.org/posts/a3470e7ffa

Pinilla, J., y Martínez, J.D. (2015). Sobre los proyectos educativos de programa de 
Contaduría Pública: una revisión del alcance de los ideales y estrategias universitarias. Trabajos de grado UDEA, 9(1). Recuperado de https:// revistas.udea.edu.co/index.php/tgcontaduria/ article/view/26731

Quiceno, H. (2002). Educación y formación profesional. Cuadernos de Administración, 18(28), 87-98. https://doi.org/10.25100/cdea. v18i28.132

Quijano, O. (2002). Armonización de la educación contable: El proyecto escolar de los gremios económicos. Cuadernos de Administración 18(28), 99-117. https://doi.org/10.25100/cdea. v18i28.133

Reyes, N., y Chaparro, F. (2013). Metodologías activas para la enseñanza de las Normas Internacionales de Información Financiera en un ambiente virtual de aprendizaje. Cuadernos de Contabilidad, 14(36), 1147-1182. Recuperado de https://revistas.javeriana.edu.co/index.php/ cuacont/article/view/7916

Rojas, W. (2015). Lectoescritura y pensamiento crítico: desafío de la educación contable. Cuadernos de Contabilidad, 16(41), 307-328. https://doi.org/10.11144/Javeriana.cc16-41.lpcd

Rojas, W., y Giraldo, G. (2015). Humanidades y formación contable: una relación necesaria para otear una reorientación de la profesión contable. Cuadernos de Contabilidad, 16(40), 261-276. $\quad$ https://doi.org/10.11144/Javeriana. cc16-40.hfcr

Rueda-Delgado, G., Pinzón, J., y Patiño, R. (2013). Los currículos de los programas académicos de contaduría pública, tras la enseñanza de lo internacional y la globalización en la contabilidad: necesidades de ajuste más allá de respuestas técnicas. Cuadernos de Contabilidad, 14(35), 639-667. Recuperado de https://revistas. javeriana.edu.co/index.php/cuacont/article/ view/7110

Sierra, G., y Santa María, M. (2002). La formación del juicio profesional: las diferencias individuales del auditor. Revista de Contabilidad, 5(10), 179-203. Recuperado de https://doaj.org/ article/69bfc45dc5b4424e99b18405a965ed6d

Stojanović, D. (2014). Conceptual framework and methods for judgment and decision-making in accounting. TEME: Casopis za Društvene Nauke,
38(4), 1573-1586. Recuperado de https://www. ceeol.com/search/article-detail $\mathrm{id}=256874$

Sunder, S. (2010). Adverse effects of uniform written reporting standards on accounting practice, education, and research. Journal of Accounting and Public Policy, 29(2), 99-114. https://doi.org/10.1016/j.jaccpubpol.2009.10.011

Terblanche, E. A. J., \& de Clercq, B. (2019). Factors to consider for effective critical thinking development in auditing students. South African Journal of Accounting. 96-114. https://doi.org/10 $.1080 / 10291954.2019 .1669293$

Universidad Católica de Oriente. (2016). Proyecto Educativo del Programa de Contaduría Pública. Recuperado de http://www.uco.edu. co/economica/contaduria/Paginas/proyectoeducativo-del-programa.aspx

Universidad Nacional de Colombia. (2012). Guía para consolidar el proyecto educativo de programa -PEP-. Recuperado de http://www. pregrado.unal.edu.co/docs/acreditacion/ general/Guia_PEP 2012.pdf

Valderrama, M., Rodríguez, B., Arias, M., Bejarano, D., Garzón, H., Salgado, J., Rueda, G., Espinosa, G., y Sosa, J. (2009). El plan de estudios del programa de Contaduría Pública de la Pontificia Universidad Javeriana frente a los retos que genera la Ley 1314 de 2009. Cuadernos de Contabilidad, (26), 113-145. Recuperado de https://repository.javeriana.edu. co/handle/10554/23813

Zamora, L. G. (2016, mayo). El juicio profesional del Contador Público y del Revisor Fiscal frente a una misma realidad. Presentada en $\mathrm{X}$ Encuentro de Profesores de Revisoría Fiscal Regulación Nacional e Internacional y ejercicio de a Revisoría Fiscal. Bogotá, Colombia: Universidad Libre. Recuperado de https://www. javeriana.edu.co/personales/hbermude/nov/ memorias rev fiscal foro firmas/eventos rev fiscal/X revisoria fiscal/PILOTO/PONENCIA UPILOTO DR LUIS GERMAN ZAMORA.pdf

Zamora, L. G. (2018). Construcción del juicio profesional del contador público. Una revisión desde la responsabilidad social. Revista Colombiana de Contabilidad, 6(11), 143-160. Recuperado de https://ojs.asfacop.org.co/index. php/asfacop/article/view/90

How to cite this paper?

Ospina Delgado, J., \& Giraldo Villano, X. (2020). Training for professional judgment in accounting education. Cuadernos de Administración, 36(67), 143-157. https://doi.org/10.25100/cdea.v36i67.7741

Cuadernos de Administración journal by Universidad del Valle is under licence Creative Commons ReconocimientoNoComercial-SinObrasDerivadas 4.0. Based in http://cuadernosdeadministracion.univalle.edu.co/ 